\title{
JURIANAI
}

Jurnal Pendidikan Ekonomi

$\therefore$ JUR KAIMI

VOLLME

5
NOMOR

2

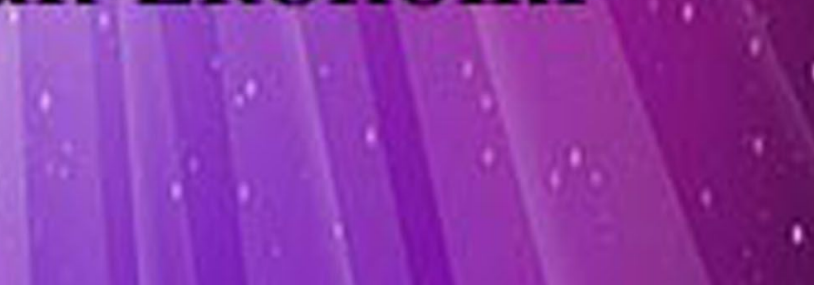




\title{
JURKAMI: Jurnal Pendidikan Ekonomi \\ http://jurnal.stkippersada.ac.id/jurnal/index.php/JPE \\ JURKAMI Volume 5, no 2, 2020
}

\section{PENGARUH KUALITAS AIR MINUM TERHADAP PEMBELIAN ULANG KONSUMEN PADA DEPOT AIR MINUM FIKRI KABUPATEN TOLITOLI}

\author{
Liem Aco ${ }^{1}$, Serlina.,SM ${ }^{2}$ \\ STIE Mujahidin Tolitoli Sulawesi Tengah ${ }^{12}$ \\ Email: liem.aco@stiemujahidin.ac.id ${ }^{1}$, serlina@gmail.com ${ }^{2}$
}

Diterima: 14 Oktober 2020; Disetujui: 30 Oktober 2020; Diterbitkan: 1 November 2020

\begin{abstract}
Water plays an important role for human needs and is used as drinking water to meet the body's metabolic needs. In order for human survival to run smoothly, clean water must also be available in sufficient quantities according to human activities in a certain place and for a certain period of time. The purpose of this study was to determine whether the quality of drinking water has an effect on consumer repurchase at the Fikri Tolitoli Drinking Water Depot. The type of research used is associative research which aims to determine the effect or relationship between two or more variables. The data analysis method used is the correlation technique / product moment and the coefficient of determination.The conclusion from this research is that the quality of drinking water has a very strong relationship with consumer re-purchase, this shows that the quality of drinking water has a significant effect on consumer re-purchase.
\end{abstract}

\section{Keywords: Drinking Water Quality, Consumer Repurchase.}

Abstrak: Air memegang peranan penting untuk kebutuhan manusia dan dimanfaatkan sebagai air minum demi memenuhi kebutuhan metabolisme tubuh. Agar kelangsungan hidup manusia dapat berjalan lancar, air bersih juga harus tersedia dalam jumlah yang memadai sesuai dengan aktifitas manusia pada tempat tertentu dan kurun waktu tertentu. Tujuan Penelitian ini adalah untuk mengetahui apakah kualitas air minum berpengaruh terhadap pembelian ulang konsumen pada Depot Air Minum Fikri Tolitoli, Adapun jenis penelitian yang digunakan yaitu penelitian Asosiatif yang bertujuan untuk mengetahui pengaruh ataupun juga hubungan antara dua variabel atau lebih. Metode analisis data yang digunakan yakni teknik korelasi/produk momen dan koefisien determinasi. Kesimpulan dari penelitian bahwa kualitas air minum sangat kuat hubungannya terhadap pembelian ulang konsumen, hal ini menunjukkan bahwa kualitas air minum berpengaruh signifikan terhadap pembelian ulang konsumen.

Kata Kunci: Kualitas Air Minum, Pembelian Ulang Konsumen 
PENDAHULUAN

Perkembangan gaya hidup Di era moderen saat ini ternyata tidak hanya terjadi dikota, dipedesaan pun mulai mengalami beragam perkembangan dibidang produk, dimana masyarakat mulai lebih cenderung menginginkan sesuatu yang instan. Hal ini bisa dilihat dari munculnya berbagai macam produk yang mulai bersaingan satu sama lain untuk menawarkan berbagai macam kelebihan sehingga membuat konsumen merasa puas dengan kualitas terhadap produk yang diberikan,

Berdasarkan Peraturan Menteri Kesehatan Nomor 492 Tahun 2010 tentang Persyaratan Kualitas Air minum, pengertian air minum adalah air yang melalui proses pengolahan atau tanpa proses pengolahan yang memenuhi syarat kesehatan dan dapat langsung diminum. Di dalam tata kehidupan masyarakat, air memegang peranan penting untuk kebutuhan manusia.Sebagai contoh untuk keperluan rumah tangga seperti kebersihan diri dan mrnyiram tanaman atau irigasi. Dari kebutuhan diri tersebutlah air dimanfaatkan sebagai air minum demi memenuhi kebutuhan metabolisme tubuh. Agar kelangsungan hidup manusia dapat berjalan lancar, air bersih juga harus tersedia dalam jumlah yang memadai sesuai dengan aktifitas manusia pada tempat tertentu dan kurun waktu tertentu.
Ditinjau dari segi kualitas, ada beberapa persyaratan yang harus dipenuhi, diantaranya kualitas fisik yang terdidri atas bau,warna dan rasa, kualitas kimia yang terdiri atas $\mathrm{pH}$, kesadahan, dan sebagainya serta kualitas biologi dimana air terbebas dari mikroorganisme penyebab penyakit,

Kualitas air secara umum menunjukkan mutu atau kondisi air yang di kaitkan dengan suatu kegiatan dengan atau keperluan tertentu. Sedangkan kualitas menyangkut jumlah air yang dibutuhkan manusia dalam kegiatan tertentu. Air adalah materi esensial di dalam kehidupan, tidak ada satupun makhluk hidup di dunia ini yang tidak membutuhkan air.

Dalam memenuhi kebutuhan terhadap air pada khususnya adalah air minum, banyak orang yang lebih mengutamakan hal-hal yang bersifat praktis.Hal ini dilakukan untuk memanfaatkan waktu di sela-sela kesibukan banyak orang dalam mencari dan memenuhi penghasilan untuk kehidupan sehari-harinya.Dengan adanya perkembangan teknologi yang semakin pesat inilah seringkali memunculkan beragam produk-produk baru yang secara praktis dapat memenuhi kebutuhan masyarakat.Salahsatu dari produk praktis itu adalah produk air minum isi ulang.

Munculnya air minum isi ulang kini lebih praktis, di dalam masyarakat sering 
disebut sebagai Air Minum Isi Ulang (AMIU) sedangkan produk dari air isi ulang dalam bentuk kemasan yang dikemas sedemikian rupa sering disebut dengan Ait Minum Dalam Kemasan (AMDK). Dengan adanya AMIU dan AMDK masyarakat telah banyak diuntungkan dari aspek ekonomis.Hal ini juga berbalik menguntungkan bagi pelaku usaha itu sendiri.Para pelaku usaha kini berlomba-lomba untuk menciptakan air minum isi ulang yang layak untuk dikonsumsi.

Berdasarkan latar belakang yang telah dikemukakan diatas, masalah pokok yang di angkat dalam penelitian ini adalah: Apakah kualitas air minum berpengaruh terhadap pembelian ulang konsumen pada depot air minum Fikri Tolitoli?.

\section{KAJIAN TEORI}

Pemasaran mempunyai peranan yang penting dalam masyarakat karena pemasaran menyangkut berbagai aspek kehidupan, termasuk bidang ekonomi dan sosial.Karena kegiatan pemasaran menyangkut masalah mengalirnya produk dari produsen ke konsumen, maka pemasaran menciptakan lapangan kerja yang penting bagi masyarakat.Dengan demikian pemasaran merupakan sektor yang penting dalam pendapatan masyarakat.Di samping itu perlu disadari bahwa sebagian besar pengeluaran uang masyarakat konsumen mengalir ke kegiatan pemasaran.

Menurut Stanton (2001), Definisi Pemasaran adalah suatu sistem keseluruhan dari kegiatan-kegiatan bisnis yang ditujukan untuk merencanakan, menentukan harga, mempromosikan dan mendistribusikan barang dan jasa yang memuaskan kebutuhan baik kepada pembeli yang ada maupun pembeli potensial.

Dari definisi tersebut di atas, dapat ditarik kesimpulan bahwa pemasaran merupakan usaha terpadu untuk menggabungkan rencana-rencana strategis yang diarahkan kepada usaha pemuas kebutuhan dan keinginan konsumen untuk memperoleh keuntungan yang diharapkan melalui proses pertukaran atau transaksi. Kegiatan pemasaran perusahaan harus dapat memberikan kepuasan kepada konsumen bila ingin mendapatkan tanggapan yang baik dari konsumen. Perusahaan harus secara penuh tanggung jawab tentang kepuasan produk yang ditawarkan tersebut. Dengan demikian, maka segala aktivitas perusahaan, harusnya diarahkan untuk dapat memuaskan konsumen yang pada akhirnya bertujuan untuk memperoleh laba.

Menurut Lupiyoadi (2006) dikatakan bahwa "manajemen pemasaran adalah suatu analisis, perencanaan, pelaksanaan, serta kontrol program-program yang telah 
direncanakan dalam hubungan dengan pertukaran-pertukaran yang diinginkan terhadap konsumen yang dituju untuk memperoleh keuntungan pribadi maupun bersama".

Dari definisi diatas dapat disimpulkan bahwa manajemen pemasaran adalah proses aplikasi fungsi-fungsi manajemen dalam aktifitas pemasaran yaitu mulai dari kegiatan perencanaan, pengorganisasian, pelaksanaan dan pengawasan terhadap seluruh kegiatan aktivitas pemasaran yang ditujukan untuk memuaskan kebutuhan dan keinginan konsumen untuk mencapai tujuan pemasaran.

Pemasaran merupakan faktor penting untuk mencapai sukses bagi perusahaan untuk mengetahui adanya cara dan falsafah yang terlibar didalamnya. Cara dan falsafah baru ini disebut konsep pemasaran. Konsep pemasaran tersebut dibuat dengan menggunakan tiga faktor dasar yaitu :

a. Saluran perencanaan dan kegiatan perusahaan harus berorientasi pada konsumen/pasar.

b. Volume penjualan yang menguntungkan harus menjadi tujuan perusahaan, dan bukannya volume untuk kepentingan volume itu sendiri.

c. Saluran kegiatan pemasaran dalam perusahaan harus dikoordinasikan dan diintegrasikan secara organisasi.

Menurut Swastha dan Irawan, (2008) Mendefinisikan konsep pemasaran sebuah falsafah bisnis yang menyatakan bahwa pemuasan kebutuhan konsumen merupakan syarat ekonomi dan sosial bagi kelangsungan hidup perusahaan. Bagi pemasaran pada suatu perusahaan memegang peranan yang sangat penting dalam rangka mencapai besarnya volume penjualan, karena dengan tercapainya sejumlah volume penjualan yang diinginkan berarti kinerja bagian pemasaran dalam memperkenalkan produk telah berjalan dengan benar. Penjualan dan pemasaran sering dianggap sama tetapi sebenarnya berbeda.

Tujuan utama konsep pemasaran adalah melayani konsumen dengan mendapatkan sejumlah laba, atau dapat diartikan sebagai perbandingan antara penghasilan dengan biaya yang layak.Ini berbeda dengan konsep penjualan yang menitikberatkan pada keinginan perusahaan.Falsafah dalam pendekatan penjualan adalah memproduksi sebuah pabrik, kemudian meyakinkan konsumen agar bersedia membelinya.

Menurut Sutrisno (1991) air minum dalam kehidupan manusia merupakan salah satu kebutuhan paling esensial, sehingga kita perlu memenuhinya dalam jumlah dan kualitas yang memadai.Selain untuk dikonsumsi air bersih juga dapat dijadiakan sebagai salah satu sarana dalam meningkatkan kesejahteraan hidup melalui upaya peningkatan derajat kesehatan. 
Berdasarkan penjelasan diatas dapat diketahui bahwa air minum merupakan suatu kebutuhan pokok untuk kelangsungan hidup, terutama manusia.Tanpa air minum manusia tidak bisa melangsungkan kehidupannya dengan baik karena tubuh manusia membutuhkan air minum terutama untuk menjaga kesehatan. Jika hal ini sudah terpenuhi maka kualitas hidup manusia akan meningkat dan bisa melaksanakan kegiatan sehari-hari dengan baik.

Sunyoto (2012) menyatakan bahwa kualitas merupakan suatu ukuran untuk menilai bahwa suatu barang atau jasa telah mempunyai nilai guna seperti yang dikehendaki atau dengan kata lain suatu barang atau jasa dianggap telah memiliki kualitas apabila berfungsi atau mempunyai nilai guna seperti yang digunakan.

Dari beberapa definisi tersebut dapat disimpulkan bahwa kualitas adalah unsur yang saling berhubungan mengenai mutu yang dapat mempengaruhi kinerja dalam memenuhi harapan pelanggan. Kualitas tidak hanya menekankan pada hasil akhir, yaitu produk dan jasa tetapi menyangkut kualitas manusia, kualitas proses, dan kualitas lingkungan. Dalam menghasilkan suatu produk dan jasa yang berkualitas melalui manusia dan proses yang berkualitas.

Menurut Aceh pedia (2010), kualitas air dapat diketahui dengan melakukan pengujian tertentu terhadap air tersebut. Pengujian yang dilakukan adalah uji kimia, fisik, biologi, atau uji kenampakan (bau dan warna). Pengelolaan kualitas air adalah upaya pemeliharaan air sehingga tercapai kualitas air yang diinginkan sesuai peruntukkannya untuk menjamin agar kondisi air tetap dalam kondisi alamiahnya.

Begitu pula dengan air bersih,air minum dan air hujan, tentunya memiliki kesamaan, namun sangat jauh berbeda diantara ketiganya. Mulai dari kandungan yang terdapat dalam air tersebut hingga sumber dari air itu sendiri. Dan tentunya penggunaan dari ketiganya juga berbeda dalam kehidupan sehari-hari.

\section{Indikator Kualitas Air Minum}

a. Jernih Atau Tidak Keruh

Air yang keruh disebabkan oleh adanya butiran-butiran koloid dari tanah liat. Semakin banyak kandungan koloid maka air semakin keruh.

b. Tidak Berwarna

Air untuk keperluan rumah tangga harus jernih. Air yang berwarna berarti mengandung bahan-bahan lain yang berbahaya bagi kesehatan.

c. Rasanya Tawar

Secara fisika, air bisa di rasakan oleh lidah. Air yang terasa asam, manis, pahit atau asin menunjukkan air tersebut tidak baik. Rasa asin disebabkan adanya garam-garam tertentu yang larut dalam air, sedangkan rasa asam diakibatkan adanya asam organik maupun asam anorganik.

d. Tidak Berbau

Air yang baik memiliki ciri tidak berbau bila dicium dari jauh maupun dari dekat. Air yang berbau busuk 
menggunakan bahan organik yang sedang mengalami dekomposisi (penguraian) oleh mikroorganisme air.

e. Temperaturnya Normal

Temperatur air sebaiknya sejuk atau tidak panas terutama agar tidak terjadi pelarutan zat kimia yang ada pada saluran/pipa, yang dapat membahayakan kesehatan dan menghambat pertumbuhan mikro organisme.

f. Tidak Mengandung Zat Padatan

Air minum tidak mengandung zat padatan yang terapung didalam air.

Keputusan pembelian menurut Nugroho (2003) adalah proses pengintegrasian yang mengkombinasi sikap pengetahuan untuk mengevaluasi dua atau lebih perilaku alternatif, dan memilih satu diantaranya.

Sedangkan menurut Helga Drumond (2003) keputusan pembelian adalah mengidentifikasikan semua pilihan yang mungkin untuk memecahkan persoalan itu dan menilai pilihan-pilihan secara sistematis dan obyektif serta sasaransasarannya yang menentukan keuntungan serta kerugiannya masing-masing.

Berdasarkan pendapat para ahli di atas maka dapat disimpulkan bahwa keputusan pembelian adalah suatu keputusan seseorang dimana dia memilih salah satu dari beberapa alternatif pilihan yang ada dan proses integrasi yang mengkombinasi sikap pengetahuan untuk mengevaluasi dua atau lebih perilaku alternatif dan memilih salah satu diantaranya.
Beberapa faktor yang mempengaruhi keputusan pembelian menurut Kotler (2000) adalah sebagai berikut :

a. Pengenalan Masalah

Proses membeli dimulai dengan pengenalan masalah dimana pembeli mengenali adanya masalah atau kebutuhan. Pembeli merasakan perbedaan antara keadaan nyata dan keadaan yang diinginkan.

b. Pencarian Informasi

Seorang konsumen yang sudah terkait mungkin mencari lebih banyak informasi tetapi mungkin juga tidak. Bila dorongan konsumen kuat dan produk yang dapat memuaskan ada dalam jangkauan, konsumen kemungkinan aka membelinya. Bila tidak, konsumen dapat menyimpan kebutuhan dalam ingatan atau melakukan pencarian informasi yang berhubungan dengan kebutuhan tersebut.

c. Evaluasi

Tahap dari proses keputusan membeli, yaitu ketika konsumen menggunakan informasi untuk mengevaluasi merek alternatif dalam perangkat pilihan. Konsep dasar tertentu membantu menjelaskan proses evaluasi konsumen.

d. Keputusan Membeli

Keputusan membeli konsumen adalah membeli merek yang paling disukai, tetapi dua faktor dapat muncul antara niat untuk membeli dan keputusan untuk membeli. Faktor pertama adalah sikap orang lain mengenai harga, produk yang akan dipilih konsumen. Faktor kedua adalah faktor situasi yang tidak diharapkan, harga yang diharapkan dan manfaat produk yang diharapkan. Akan tetapi peristiwaperistiwa tang tak diharapkan bisa menambah niat pembelian.

e. Paska Pembelian

Konsumen mendasarkan harapan mereka pada informasi yang mereka terima dari penjual, teman dan sumbersumber yang lain. Bila penjual melebih- 
lebihkan prestasi produknya, harapan konsumen tidak akan terpenuhi dan hasilnya ketidak puasan. Semakin besar kesenjangan antara harapan dan prestasi,

Dalam penelituan ini akan digunakan beberapa indikator untuk mengukur variabel keputusan pembelian ulang Tjiptono Fandy dan Gregorius Chandra (2012) yaitu :

a. Melakukan Pembelian Ulang

b. Merekomendasikan Pada Orang Lain

c. Tidak Ingin Pindah Ke Merek lain

Menurut Dewi (2013), konsumen adalah seseorang yang menggunakan produk atau jasa yang dipasarkan.

Sedangkan kepuasan konsumen adalah sejauh mana hrapan para pembelian seorang konsumen dipenuhi atau bahkan dilebihi oleh sebuah produk. Jika harapan konsumen tersebut dipenuhi maka ia akan merasa puas, dan jika melebihi harapan konsumen, maka konsumen akan merasa senang.

Konsumen dibagi menjadi dua kategori, yaitu konsumen personal dan konsumen organisasional. Konsumen personal adalah individual yang membeli barang dan jasa untuk digunakan sendiri, untuk penggunaan dalam rumah tangga, anggota keluarga dan teman. Sedangkan konsumen organisasional merupakan sebuah perusahaan, agen pemerintah atau institusi profit maupun nonprofit lainnya yang membeli barang, jasa dan peralatan lain yang diperlukan dan digunakan agar organisasi tersebut dapat berjalan dengan baik.

\section{METODOLOGI PENELITIAN}

Jenis penelitian yang digunakan dalam penelitian ini yaitu penelitian asosiatif. Menurut Sugiyono (2003) penelitian asosiatif merupakan penelitian yang bertujuan untuk mengetahui pengaruh ataupun juga hubungan antara dua variable atau lebih. Penelitian ini mempunyai tingkat tertinggi dibandingkan dengan deskriptif dan komparatif karena dengan penelitian ini dapat dibangun suatu teori yang dapat berfungsi untuk menjelaskan, meramalkan dan mengontrol suatu gejala.

Skala likert digunakan untuk mengukur sikap, pendapat dan persepsi seseorang atau kelompok tentang fenomena tertentu. Pengisian koesioner dilakukan dengan cara selft administration, dimana responden mengisi sendiri kusionernya. Dengan demikian responden dapat mengekspresikan pendapat dan jawabannya tanpa takut jawabannya diketahui orang lain. Adapun tabel dan kata-kata yang terdapat pada Tabel skala likert berikut ini :

Tabel 1: Skala Angket

\begin{tabular}{lc}
\hline Kategori & Skor \\
\hline Sangat Setuju (SS) & 5 \\
\hline Setuju (S) & 4 \\
\hline Netral (N) & 3 \\
\hline Tidak Setuju(TS) & 2 \\
\hline Sangat Tidak Setuju (STS) & 1 \\
\hline
\end{tabular}


Kegiatan dalam analisis data adalah mengelompokkan data berdasarkan variabel dan jenis responden, mentabulasi data berdasarkan variabel dari seluruh responden, menyajikan data dari tiap variabel yang diteliti,

Korelasi produk momen atau product of the moment correlation adalah salah satu teknik untuk mencari korelasi antar dua variabel yang kerap kali digunakan. Dikatakan korelasi produk momen karena koefisien korelasinya diperoleh dengan cara mencari hasil perkalian dari momen-momen variabel yang dikorelasikan (product of the moment) Sudijono (2010). Teknik korelasi produk momen bertujuan untuk mengetahui kuat atau tidaknya pengaruh antara satu variabel dengan variabel lainnya. adapun tabel Pedoman untuk memberikan interpretasi Nilai Korelasi Variabel Penelitian sebagai berikut :

Tabel 2: Interpretasi Product moment

\begin{tabular}{cc}
\hline $\begin{array}{c}\text { Besarnya }(\mathrm{r}) \\
\text { Product } \\
\text { moment } \\
\left(\mathrm{r}_{\mathrm{xy}}\right)\end{array}$ & Interpretasi \\
\hline $0,00-0,20$ & Tidak ada korelasi \\
\hline $0,20-0,40$ & Korelasi rendah \\
\hline $0,40-0,70$ & Kuat dan tinggi \\
\hline $0,90-1,00$ & Sangat kuat dan sangat \\
\hline
\end{tabular}

Uji Koefisien Determinasi Untuk mengetahui besarnya pengaruh antara variabel X (Kualitas Air Minum) dengan variabel Y (Pembelian Ulang Konsumen) dapat dilakukan dengan menghitung koefisien determinasinya. Maka mencari koefisien determinasinya dilakukan dengan rumus :

$\mathrm{KD}=\left(\mathbf{r}^{2}\right) \times 100 \%$

Keterangan :

$\mathrm{KD}=$ Koefisien Determinasi

$\mathrm{r}=$ Korelasi Antara Variabel $\mathrm{X}$

Dengan Variabel Y

\section{HASIL DAN PEMBAHASAN}

Karakteristik responden dalam penelitian ini merupakan gambaran dari pelanggan depot air minum isi ulang fikri sebanyak 54 orang. Analisis data ini bertujuan untuk memperoleh informasi mengenai identitas invidu yang meliputi jenis kelamin, usia, pekerjaan terakhir dan frekuensi pembelian. Lebih jelasnya ditampilkan melalui tabel berikut :

Tabel 3: Karakteristik Responden Berdasarkan Jenis Kelamin

\begin{tabular}{ccc}
\hline Jenis Kelamin & $\begin{array}{c}\sum \\
\text { Responden }\end{array}$ & $\mathbf{( \% )}$ \\
\hline Laki-Laki & 33 & $0,62 \%$ \\
\hline Perempuan & 21 & $0,38 \%$ \\
\hline Jumlah & $\mathbf{5 4}$ & $\mathbf{1 0 0 \%}$ \\
\hline
\end{tabular}

Sumber : Data Primer diolah, 2020

Tabel 3 menunjukkan bahwa sebanyak 33 responden $(0,62 \%)$ berjenis kelamin laki-laki, sedangkan yang berjenis kelamin perempuan yaitu 21 responden $(0,38 \%)$. Berdasarkan hasil tabel dapat disimpulkan bahwa yang paling banyak melakukan pembelian adalah berjenis kelamin laki-laki. 
Tabel 4: Karakteristik Responden

Berdasarkan Usia

\begin{tabular}{ccc}
\hline Usia & $\sum$ Responden & $(\boldsymbol{\%})$ \\
\hline$<17$ tahun & 4 & $0,07 \%$ \\
\hline $17-30$ & 20 & $0,37 \%$ \\
\hline $31-40$ & 23 & $0,43 \%$ \\
\hline $41-50$ & 7 & $0,13 \%$ \\
\hline$>50$ tahun & 0 & $0 \%$ \\
\hline Jumlah & $\mathbf{5 4}$ & $\mathbf{1 0 0 \%}$ \\
\hline
\end{tabular}

Sumber : Data Primer diolah, 2020

Dengan demikian jika ditinjau dari faktor responden dapat memberikan gambaran para responden memiliki potensi untuk berfikir dan mengambil keputusan serta bertindak dalam melakukan pembelian.

Tabel 5: Karakteristik Responden Berdasarkan Pekerjaan

\begin{tabular}{ccc}
\hline $\begin{array}{c}\text { Pekerjaan } \\
\text { (Tahun) }\end{array}$ & $\sum$ Responden & $\mathbf{( \% )}$ \\
\hline PNS & 12 & $0,22 \%$ \\
\hline Pegawai & 6 & $0,11 \%$ \\
\hline Mahasiswa & 9 & $0,17 \%$ \\
\hline TNI/POLRI & 5 & $0,10 \%$ \\
\hline Wiraswasta & 8 & $0,14 \%$ \\
\hline Lain-lain & 14 & $0,26 \%$ \\
\hline Jumlah & $\mathbf{5 4}$ & $\mathbf{1 0 0 \%}$
\end{tabular}

Sumber : Data Primer diolah, 2020

Tabel 5 menyatakan bahwa PNS sebanyak 12 responden $(0,22 \%)$, pegawai swasta sebanyak 6 responden $(0,11 \%)$, Mahasiswa sebanyak 9 responden $(0,17 \%)$, TNI/POLRI sebanyak $(0,10 \%)$, wiraswasta sebanyak 8 responden $(0,14 \%)$, sedangkan lain-lain sebanyak 14 responden $(0,26 \%)$. Dapat disimpulkan bahwa lain-lain lebih banyak melakukan pembelian pada Depot Air Minum Isi Ulang Fikri.

\section{Kualitas Air Minum}

Penelitian ini dilakukan untuk membahas kualitas air minum (x) dan pembelian ulang konsumen (y) pada depot air minum fikri. Adapun tanggapan responden mengenai Air yang di jual oleh depot fikri sangat jernih karena tersaring sedemikian rupa adalah sebagai berikut :

Tabel 6: Air yang dijual oleh depot fikri sangat jernih karena tersaring sedemikian rupa

\begin{tabular}{lccc}
\hline \multicolumn{2}{l}{ Skala Pengukuran Skor } & Frekuensi & $\mathbf{( \% )}$ \\
\hline Setuju & 5 & 26 & $48 \%$ \\
\hline Netral & 4 & 23 & $43 \%$ \\
\hline Tidak Setuju & 3 & 5 & $9 \%$ \\
\hline Sangat Tidak Setuju & 2 & 0 & $0 \%$ \\
\hline Sangat Setuju & 1 & 0 & $0 \%$ \\
\hline Jumlah & & 54 & $100 \%$ \\
\hline
\end{tabular}

Sumber : Data Primer diolah, 2020

Adapun tanggapan responden mengenai Air yang tersedia di depot fikri higienis dan tidak berwarna, artinya bening atau transparan.

Tabel 7: Air yang tersedia higienis dan tidak berwarna

\begin{tabular}{|c|c|c|c|}
\hline Skala Pengukuran & Skor & Frekuensi & $(\%)$ \\
\hline Setuju & 5 & 26 & $48 \%$ \\
\hline Netral & 4 & 16 & $30 \%$ \\
\hline Tidak Setuju & 3 & 12 & $22 \%$ \\
\hline Sangat Tidak Setuju & 2 & 0 & $0 \%$ \\
\hline Sangat Setuju & 1 & 0 & $0 \%$ \\
\hline Jumlah & & 54 & $100 \%$ \\
\hline
\end{tabular}

Sumber : Data Primer diolah, 2020

Adapun tanggapan responden mengenai Airnya memiliki rasa yang tawar sehingga kami dapat menikmati air tersebut adalah sebagai berikut : 
Tabel 8: Airnya memiliki rasa yang tawar

\begin{tabular}{lccc}
\hline \multicolumn{1}{l}{ Skala Pengukuran Skor } & Frekuensi & $\mathbf{( \% )}$ \\
\hline Sangat Setuju & 5 & 20 & $37 \%$ \\
\hline Setuju & 4 & 24 & $44 \%$ \\
\hline Netral & 3 & 8 & $15 \%$ \\
\hline Tidak Setuju & 2 & 2 & $4 \%$ \\
\hline Sangat Tidak Setuju & 1 & 0 & $0 \%$ \\
\hline Jumlah & & 54 & $100 \%$ \\
\hline
\end{tabular}

Sumber : Data Primer diolah, 2020

Adapun tanggapan responden

mengenai Air yang diproduksi yaitu air baik dan tidak berbau adalah sebagai berikut :

Tabel 9: Air yang diproduksi yaitu air baik dan tidak berbau

\begin{tabular}{lccc}
\hline \multicolumn{1}{c}{ Skala Pengukuran } & Skor & Frekuensi & $\mathbf{( \% )}$ \\
\hline Sangat Setuju & 5 & 19 & $35 \%$ \\
\hline Setuju & 4 & 14 & $26 \%$ \\
\hline Netral & 3 & 20 & $37 \%$ \\
\hline Tidak Setuju & 2 & 1 & $2 \%$ \\
\hline Sangat Tidak Setuju & 1 & 0 & $0 \%$ \\
\hline Jumlah & & 54 & $100 \%$ \\
\hline
\end{tabular}

Sumber : Data Primer diolah, 2020

Adapun tanggapan responden mengenai Air yang diproduksi pada depot fikri sejuk atau tidak panas adalah sebagai berikut :

Tabel 10: Air yang diproduksi pada depot fikri sejuk atau tidak panas

Skala Pengukuran Skor Frekuensi (\%)

\begin{tabular}{lccc}
\hline Setuju & 5 & 20 & $37 \%$ \\
\hline Netral & 4 & 24 & $44 \%$ \\
\hline Tidak Setuju & 3 & 8 & $15 \%$ \\
\hline Sangat Tidak Setuju & 2 & 2 & $4 \%$ \\
\hline Sangat Setuju & 1 & 0 & $0 \%$ \\
\hline Jumlah & & 54 & $100 \%$ \\
\hline
\end{tabular}

Sumber : Data Primer diolah, 2020

Adapun tanggapan responden mengenai Depot fikri tidak menggunakan zat yang berbahaya pada air yang diproduksi sehingga air aman untuk dikonsumsi adalah sebagai berikut :

Tabel 11: Tidak menggunakan zat yang berbahaya pada air yang diproduksi Skala Pengukuran Skor Frekuensi (\%)

\begin{tabular}{lccc}
\hline Sangat Setuju & 5 & 19 & $35 \%$ \\
\hline Setuju & 4 & 14 & $26 \%$ \\
\hline Netral & 3 & 20 & $37 \%$ \\
\hline Tidak Setuju & 2 & 1 & $2 \%$ \\
\hline Sangat Tidak Setuju & 1 & 0 & $0 \%$ \\
\hline Jumlah & & 54 & $100 \%$ \\
\hline Sumber
\end{tabular}

Sumber : Data Primer diolah, 2020

Hasil dari deskriptif pembelian ulang konsumen berdasarkan indikator yang telah ditentukan pada penelitian dapat diuraikan dalam tabel berikut ini :

Tabel 12: Berminat untuk membeli ulang dan menggunakan air minum yang diproduksi depot fikri

\begin{tabular}{lccc}
\hline Skala Pengukuran & Skor & Frekuensi & $\mathbf{( \% )}$ \\
\hline Sangat Setuju & 5 & 17 & $31 \%$ \\
\hline Setuju & 4 & 29 & $54 \%$ \\
\hline Netral & 3 & 6 & $11 \%$ \\
\hline Tidak Setuju & 2 & 2 & $4 \%$ \\
\hline Sangat Tidak Setuju & 1 & 0 & $0 \%$ \\
\hline Jumlah & & 54 & $100 \%$ \\
\hline Sumber
\end{tabular}

Sumber : Data Primer diolah, 2020

$$
\text { Adapun tanggapan responden }
$$
mengenai Saya akan menyarankan teman atau kerabat untuk membeli produk yang ditawarkan depot fikri karena pelayanan yang memuaskan adalah sebagai berikut :

\section{Tabel 13: Menyarankan teman atau} kerabat untuk membeli produk yang ditawarkan depot fikri

Skala Pengukuran Skor Frekuensi (\%)

\begin{tabular}{lccc}
\hline Sangat Setuju & 5 & 8 & $15 \%$ \\
\hline Setuju & 4 & 31 & $57 \%$ \\
\hline Netral & 3 & 15 & $28 \%$ \\
\hline Tidak Setuju & 2 & 0 & $0 \%$ \\
\hline Sangat Tidak Setuju & 1 & 0 & $0 \%$ \\
\hline
\end{tabular}




\begin{tabular}{lrr}
\hline Jumlah & 54 & $100 \%$ \\
\hline
\end{tabular}

Sumber : Data Primer diolah, 2020

Adapun tanggapan responden mengenai Saya tidak ingin pindah ke tempat lain karena saya sudah merasa nyaman dan puas membeli produk di depot fikri adalah sebagai berikut :

Tabel 14: Tidak ingin pindah ke tempat lain

\begin{tabular}{lccc}
\hline $\begin{array}{c}\text { Skala } \\
\text { Pengukuran }\end{array}$ & Skor & Frekuensi & $(\boldsymbol{\%})$ \\
\hline Sangat Setuju & 5 & 17 & $31 \%$ \\
\hline Setuju & 4 & 25 & $46 \%$ \\
\hline Netral & 3 & 12 & $22 \%$ \\
\hline Tidak Setuju & 2 & 0 & $0 \%$ \\
\hline $\begin{array}{l}\text { Sangat Tidak } \\
\text { Setuju }\end{array}$ & 1 & 0 & $0 \%$ \\
\hline Jumlah & & 54 & $100 \%$ \\
\hline
\end{tabular}

Sumber : Data Primer diolah, 2020

Untuk menghitung hubungan antara kualitas air minum (X) terhadap pembelian ulang konsumen (Y) maka hasil perhitungan sebagai berikut :

$r_{x y}=\frac{\sum x y}{\sqrt{\left(\sum x^{2}\right)\left(\sum y^{2}\right)}}$

$\mathrm{r}_{\mathrm{xy}}=\frac{16209}{\sqrt{(33124)(8023)}}$

$r_{x y}=\frac{16209}{\sqrt{265753852}}$

$r_{x y}=\frac{16209}{16301}$

$r_{x y}=0,99 \%$

Dari perhitungan di atas maka koefisien korelasi yang ditemukan sebesar 0,99\% termaksud pada kategori sangat kuat. Jadi terdapat hubungan yang sangat kuat dan sangat tinggi antara Kualitas Air
Minum Terhadap Pembelian Ulang Konsumen. Analisis Koefisien determinasi adalah untuk mengetahui besarnya pengaruh Kualitas Air Minun (X) dengan Pembelian Ulang konsumen (Y) dapat dilakukan dengan menghitung koefisien determinasinya berikut ini :

$$
\begin{aligned}
K d & =(\mathrm{r})^{2} \times 100 \% \\
K d & =(0,99)^{2} \times 100 \% \\
K d & =0,9801 \times 100 \% \\
K d & =98,01 \%
\end{aligned}
$$

Nilai koefisien determinasi $98,01 \%$ memberikan arti bahwa Kualitas Air Minum Terhadap Pembelian Ulang Konsumen adalah sebesar 98,01\% termasuk dalam kategori signifikan dan sangat kuat

\section{PENUTUP}

Berdasarkan hasil pembahasan yang telah diuraikan sebelumnya, maka dapat disimpulkan sebagai berikut: Nilai koefisien korelasi (r) 0,99 atau 99\% adalah angka positif. Hal ini menunjukkan hubungan antara kualitas air minum (X) terhadap pembelian ulang konsumen $(\mathrm{Y})$ yaitu sangat kuat, karena telah mendekati 1. Hal ini menunjukkan bahwa kualitas air minum sangat kuat hubungannya terhadap pembelian ulang konsumen; Nilai koefisien determinasi $(r)^{2} \quad 0,9801$ atau 98,01\% yang berarti kualitas air minum berpengaruh terhadap pembelian ulang konsumen, sedangkan sisanya $1,99 \%$ 
JURKAMI: Jurnal Pendidikan Ekonomi

dipengaruhi oleh variabel lain yang tidak termasuk dalam penelitian ini. Hal ini menunjukkan bahwa kualitas air minum berpengaruh signifikan dan sangat kuat terhadap pembelian ulang konsumen.

\section{DAFTAR PUSTAKA}

Aceh pedia, 2010. "Fungsi Unsur Hara", Diakses dari http://acehpedia.org/Fungsi Unsur Hara. Diakses 20 Juni 2018

Amalia, Dewi 2013. "Pengaruh Karakteristik Perusahaan Terhadap Corporate Social Responsibility Disclosure di Bursa Efek Indonesia" Media Riset Akuntansi, Vol, 3 No. 1 Februari 2013.

Anas Sudijono 2010. Pengantar Statistik Pendidikan, Rajawali Press. Jakarta.

Basu Swastha dan Irawan 2008, Manajemen Pemasaran Analisis Perilaku Konsumen, Liberty, Yogyakarta.

Drumond Helga, 2003. “Metode Penelitian Bisnis", Jilid 1, Edisi 5, Erlangga, Jakarta.

J. Setiadi, Nugroho, 2003. "Perilaku Konsumen", Penerbit PT. Kencana Perdana Media. Jakarta

Kotler, Philip, 2000. "Manajemen Pemasaran", Edisi Melenium, Jakarta : Prehalindo.

Lupiyoadi dan Hamdani 2006. Manajemen Pemasaran Jasa Edisi kedua Penerbit Salemba Empat, Jakarta.

Peraturan Menteri Kesehatan RI. No.492/MENKES/PER/IV/2010

Tentang Persyaratan Kualitas Air Minum Tahun 2010
JURKAMI Volume 5, no 2, 2020 | 101

Stanton, William J. 2001. "Prinsip Pemasaran", Jilid 1 Edisi ke 3 Erlangga. Jakarta :

Sugiyono, 2003. "Metode Penelitian Bisnis", Edisi 1, CV.Alfabeta, Bandung.

Sunyoto, Danang, 2012. "Manajemen Sumber Daya Manusia", PT.Buku Seru, Jakarta

Sutrisno, T. Eni Suciastuti, 1991. Teknologi Penyediaan Air Bersih, Bhineka Cipta, Jakarta.

Tjiptono Fandy dan Gregorius Chandra 2012, Pemasaran Strategik, ANDI, Yogyakarta. 